\title{
Long-term Effects of Annual Burning at Dif- ferent Dates in Ungrazed Kansas Tallgrass Prairie
}

\author{
GENE TOWNE AND CLENTON OWENSBY
}

\begin{abstract}
Ungrazed tallgrass prairie plots in the Kansas Flint Hills have been burned annually at 4 different dates since 1928. Time of burning markedly altered the physiognomy and was the crucial factor effecting vegetation change. Late-spring burning, coinciding with emergence of the warm-season perennial grasses, increased grass production and favored $A$ ndropogon gerardii and Sorghastrum nutans. Burning in winter, early-spring, or mid-spring reduced herbage production and shifted vegetational composition by differentially favoring other species. Andropogon scoparius increased with mid- and early-spring burning, while perennial forbs and sedges increased with early-spring and winter burning. Amorpha canescens was favored by all burning treatments. Mulch buildup in unburned, undisturbed plots increased Poa pratensis and tree species and eventually reduced grass production. The long-term effects of annual late-spring burning, even in dry years, was not detrimental to herbage production, species composition, or total basal cover in tallgrass prairie.
\end{abstract}

Tallgrass prairie is fire-derived and fire-maintained (Stewart 1951). Historically, fires were intermittent and occurred at nearly any time of the year (Jackson 1965). In the 1880's, cattlemen observed that transient steers gained more weight on burned than on unburned range, and as a result, grazing leases later mandated annual burning (Kollmorgen and Simonett 1965). Time of burning, however, was of little concern, and most pastures were burned in January or February to stimulate earlier greenup.

Although voluminous literature exists on vegetational effects from fire, few studies have acknowledged the importance of time of burning. Aldous (1934) initiated preliminary research on burning ungrazed tallgrass prairie at different dates. Subsequent reports on herbage production (McMurphy and Anderson 1963) and botanical composition (McMurphy and Anderson 1965) were nonreplicated, short-term studies in which the unburned control was mowed and raked annually, and included data from years when the plots were not burned. This paper compiles earlier research and adds recent data from undisturbed control plots to evaluate the importance of time of burning on herbage production and species composition in ungrazed tallgrass prairie over the past 56 years.

\section{Study Area and Methods}

The experimental site is located on a level ridge top in the Kansas Flint Hills north of Manhattan. From the early 1900's, the area had been moderately grazed by cattle and routinely burned in late winter. Soil at the site is a loessial-derived Smolan silt loam classified as a Pachic Argiustoll. It has a dark-gray surface layer about $20 \mathrm{~cm}$ thick overlying a deep silty clay loam subsoil. Vegetation at the beginning of the study was predominantly little bluestem

Authors are research assistant and range research scientist, Department of Agronomy. Kansas State University, Manhattan 66506. The voluntary efforts of Doreen Towne in manuscript word processing are greatly appreciated.

Additional graphs of yearly fluctuations for the major plant species under different burning treatments are available from the authors on request.

This report is Contribution No. 83-135-J, Department of Agronomy, Kansas Agricultural Experiment Station, Manhattan 66506.

Manuscript accepted December 29, 1983
(Andropogon scoparius Michx.) ${ }^{1}$, with prairie junegrass [Koeleria pyramidata (Lam.) Beauv.], big bluestem (A. gerardii Vitman), and indiangrass [Sorghastrum nutans (L.) Nash] also prevalent (Table 1). Mean annual precipitation for Manhattan since 1928 is

Table 1. Percent botanical composition based on actual stem numbers in 1926 on Kansas Flint Hills study site before date of burning treatments began.

\begin{tabular}{lc}
\hline \hline & $\%$ \\
\hline Andropogon scoparius Michx. & 32.6 \\
Koeleria pyramidata (Lam.) Beauv. & 20.2 \\
Andropogon gerardii Vitman & 16.7 \\
Sorghastrum nutans (L.) Nash & 11.0 \\
Poa pratensis L. & 1.0 \\
Panicum virgatum L. & 0.2 \\
Other perennial grasses & 8.9 \\
Annual grasses & 0.0 \\
Sedges & 3.1 \\
Perennial forbs & 6.1 \\
Annual and biennial forbs & 0.2 \\
Woody plants & 0.0 \\
\hline
\end{tabular}

$82.8 \mathrm{~cm}$, ranging from $39.2 \mathrm{~cm}$ in 1966 to $153.4 \mathrm{~cm}$ in 1951 . Rainfall generally is highest in spring and then declines through the summer. Average frost-free period is 178 days, extending from April 22 to October 17.

To study the effects of burning tallgrass prairie on different dates, a 0.4 -ha area was fenced in 1926. Surrounding pasture land has been continuously grazed and annually supports dense stands of Japanese brome (Bromus japonicus Thunb.), common ragweed (Ambrosia artemisiifolia L.), woolly verbena (Verbena stricta Vent.), and numerous other forbs, but no trees are in close proximity. The enclosed site was partitioned into ten $20 \times 10-\mathrm{m}$ plots separated by $0.9-\mathrm{m}$ alleys. Treatments were winter burn (December 1), early-spring burn (March 20), mid-spring burn (April 10), late-spring burn (May 1), and unburned. Actual dates of burning varied throughout the years depending upon seasonal weather conditions. Initially, 1 set of 4 plots was burned annually beginning in December 1926, and another set biennially burned. Starting in 1950 , however, the plots formerly burned in alternate years were burned yearly to provide 2 replications for each treatment. Burning was discontinued from 1935-1937 and from 1945-1949. But for 48 of the past 56 years the research plots have been burned, representing, to our knowledge, the longest extent of burning studies in existence.

Initially, unburned control plots were mowed and the cut material removed every year before spring growth to prevent excess mulch accumulations. That practice, however, obscured differences between burned and unburned treatments and was stopped in 1968. Both unburned plots were accidentally burned by wild lifes in January 1951 and again in March 1966.

IScientific names follow McGregor and Barkley (1977) 


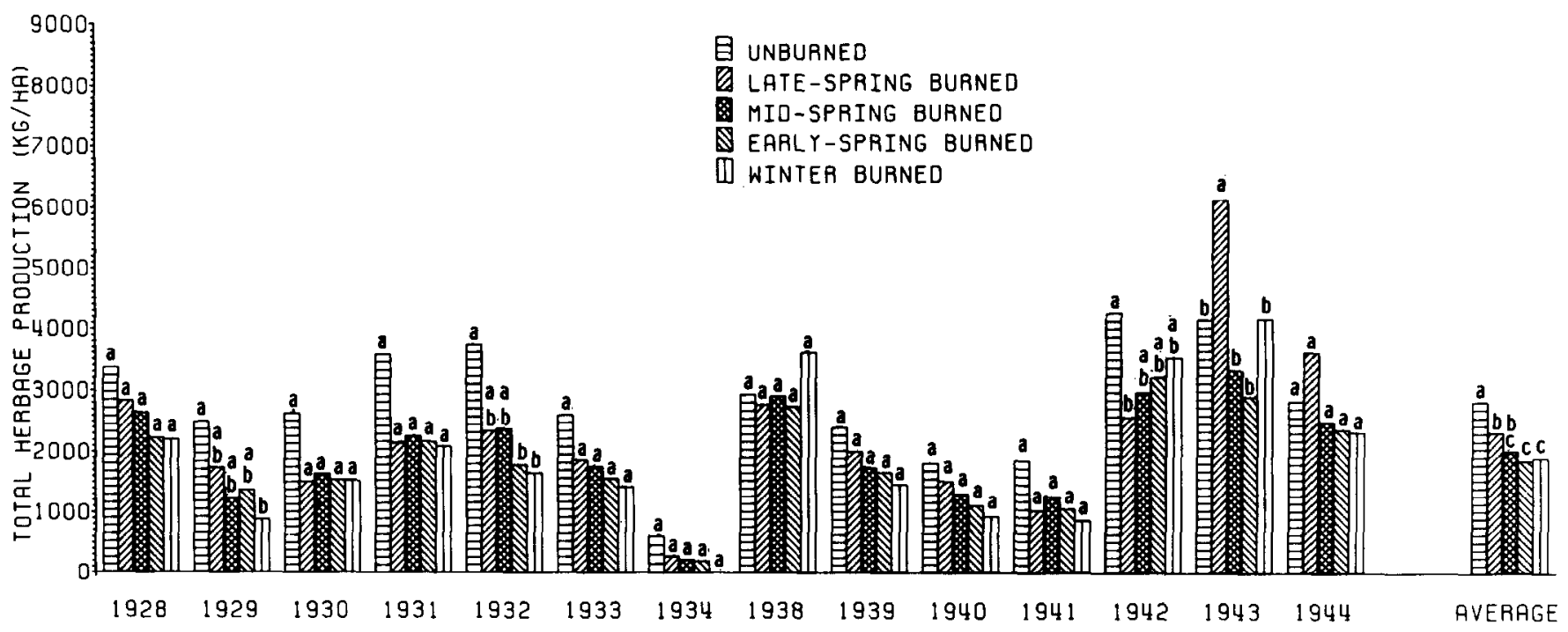

Fig. 1. Total annual herbage production ( $\mathrm{kg} / \mathrm{ha}$ oven-dry weight) from 1928 -1944 under different burning dates. One replication per treatment. Unburned plots were mowed and raked annually in late-spring. Means within each year having the same letter are not significantly different (P>.05).

Total herbage production for each plot was measured annually at the end of the growing season, normally in early-October. Current year's biomass was harvested by mowing swaths to a $5-\mathrm{cm}$ stubble height from 1928-1971, and by clipping four 0.4- $\mathrm{m}^{2}$ quadrats per plot to ground level beginning in 1972. Prior to 1965, yields had been on an air-dry basis and were converted to approximate oven-dry weights by reducing the yields $10 \%$. Plots were not harvested from 1945-1952. Yearly herbage yields were excluded from statistical analysis when plots were not burned (1935-1937), when all plots accidentally burned (1966), and in 1971, when erroneous sampling inflated production. Beginning in 1973, clipped herbage was segregated into grasses (including sedges) and forbs (including woody species). Mulch and old standing dead in unburned plots were removed from each quadrat prior to clipping and were not included in herbage production data.

Botanical composition was usually estimated by mid-June. From 1928-1942, actual stem numbers of plant species were counted in 2 permanent meter-square quadrats in each plot. No plant census was taken from 1943-1949. From 1950-1974, basal cover and species composition were estimated by randomized line transects (Anderson 1942). Beginning in 1975, relative percentages of plant species and basal cover were determined by the modified step-point technique (Owensby 1973). To analyze the vegetational response from date of burning treatments, we segregated out 5 primary perennial grass species, and grouped other grasses, forbs, and woody species into appropriate catcgories.

All data were statistically analyzed by standard analysis of variance and treatment means separated by Duncan's multiple range test $(P<.05)$. Because of variations in data collection, herbage yields were analyzed separately for 3 time periods: (1) from 1928-1944 when there was only one treatment replication and thus no interaction variability; (2) from 1950-1967 when unburned plots were annually mowed and raked; (3) from 1968-1982 when mulch was allowed to accumulate on the unburned plots. Herbage

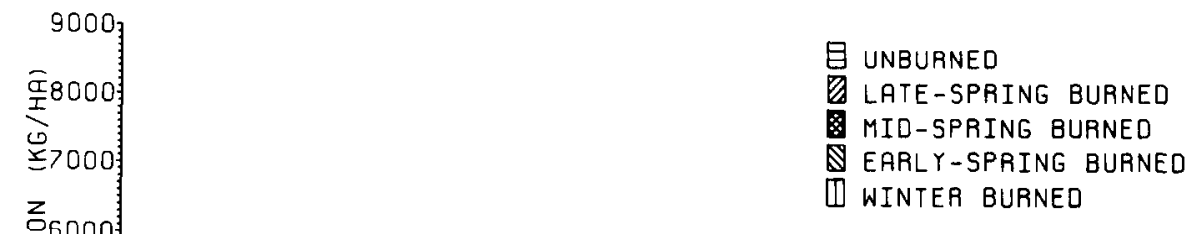

늠

它 5000

产

出

品3000

I

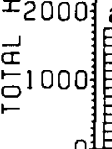
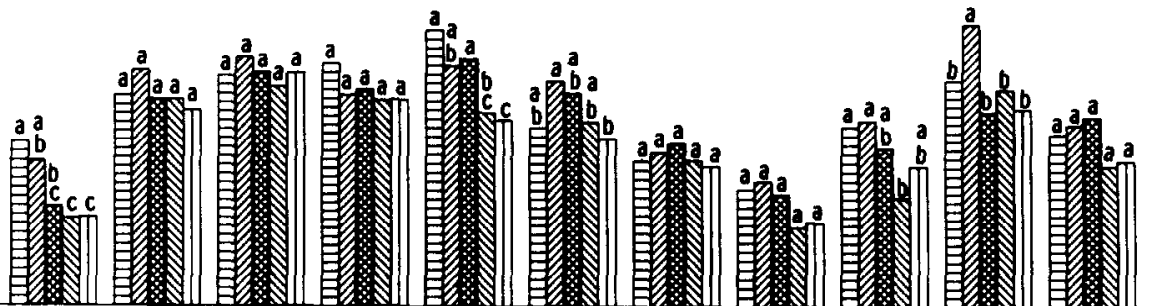

$\begin{array}{lllll}1953 & 1954 & 1955 & 1956 & 1957\end{array}$

1958

1959

1960

1961

1962

1963

1964

1965

1967

AVERAGE

Fig. 2. Total annual herbage production ( $\mathrm{kg} / \mathrm{ha}$ oven-dry weight) from 1953-1967 under different burning dates. Two replications per treatment. Unburned plots were mowed and raked annually in late-spring. Means within each year having the same letter are not significantly different $(\mathbf{P}>.05)$. 
Table 2. Correlation coefficients (r) of total herbage yields from 1928-1982 for date of burning treatments and independent precipitation variables.

\begin{tabular}{|c|c|c|c|c|c|}
\hline Precipitation & Unburned & Late-spring burn & Mid-spring burn & Early-spring burn & Winter burn \\
\hline Yearly total & $.28 *$ & $.37^{*}$ & $.32^{*}$ & $.35^{*}$ & $.36^{*}$ \\
\hline Previous years total & $.31 *$ & .23 & .23 & $.29 *$ & $.26^{*}$ \\
\hline January-April & .03 & $.24^{*}$ & .19 & .24 & .17 \\
\hline May-June & .17 & $.30^{*}$ & $.25^{*}$ & $.29 *$ & $.36^{*}$ \\
\hline May-September & .24 & $.28^{*}$ & .23 & $.26^{*}$ & $.31 *$ \\
\hline
\end{tabular}

$* P<.05$

production and species composition from the burning treatments were correlated with 5 selected combinations of precipitation: yearly total; previous year's total; amount prior to growing season (January-April); amount during early portion of growing season (May-June); and amount during entire growing season (MaySeptember).

\section{Results and Discussion}

\section{Herbage Production}

Herbage yields fluctuated greatly throughout the years, ranging from $8,455 \mathrm{~kg} / \mathrm{ha}$ in $1981 \mathrm{mid}$-spring burned plots to $0 \mathrm{~kg} / \mathrm{ha}$ in 1934 winter burned plots. Total herbage production in all burning treatments was highest in 1981 and second highest the following year, indicating that long-term annual burning does not decrease prairie productivity.

In the first phase of the study, average herbage production was significantly reduced by burning at any time compared to not burning (Fig. 1). However, the effects were not uniform over time. In only 3 of the 14 years did unburned plots produce significantly more biomass than any burned plot.

A significant interaction between burning and year of treatment in both the second and third phase of the study indicated total herbage yields were affected by date of burning more in some years than in others (Fig. 2 and 3). McMurphy and Anderson (1963) speculated that the greatest reduction in herbage yields from burning occurred in the driest seasons. However, correlation coefficients disclosed a weak relationship between herbage yields and time of burning over all precipitation variables (Table 2). Although most of the independent variables were significant, the low coefficient values indicate that only a small portion of the variation in herbage yields can be attributed to precipitation factors. In years with annual precipitation at least $10 \%$ below normal, late-spring burning never significantly reduced herbage production compared to unburned plots. Thus, contrary to rumored opinion, burning tallgrass prairie at the proper time, even in dry years, does not adversely affect herbage yields.

In other geographic regions, studies of vegetational response to wildfires or prescribed burns occurring at inopportune times often have neglected to take into account the time of burning. Although fire intensity, fuel source, and soil moisture are all potentially important in influencing vegetational response to fire, time of burning is the proxy for these factors, and in this study was the crucial factor ultimately affecting herbage production. Since 1928 , burning in winter and early-spring has reduced total herbage yields an average of $15 \%$ and $16 \%$, respectively, over plots burned in late-spring. Anderson (1965) attributed that to a reduction in soil moisture due to decreased infiltration and increased evaporation. Bieber and Anderson (1961) found progressively lower soil moisture the earlier an area was burned in relation to initiation of spring growth; however, there was no significant difference between unburned and late-spring burned plots. Burning at a time to minimize surface exposure will thus curtail soil moisture loss and prevent concomitant herbage reduction.

Differences in herbage yields between burned and unburned plots prior to 1968 are misleading because the unburned plots were mowed and raked annually. Mechanical mulch removal increases total biomass production in tallgrass prairie (Penfound 1964). Higher soil temperatures on areas denuded early in the growing season by either clipping or burning are responsible for the increased productivity (Hulbert 1969, Rice and Parenti 1978, Adams and Anderson 1978). Mulch accumulations in undisturbed prairie eventually depress herbage yields and reduce the number of plant species (Weaver and Rowland 1952). After mulch removal was halted in 1968, unburned plots continued to yield more her-

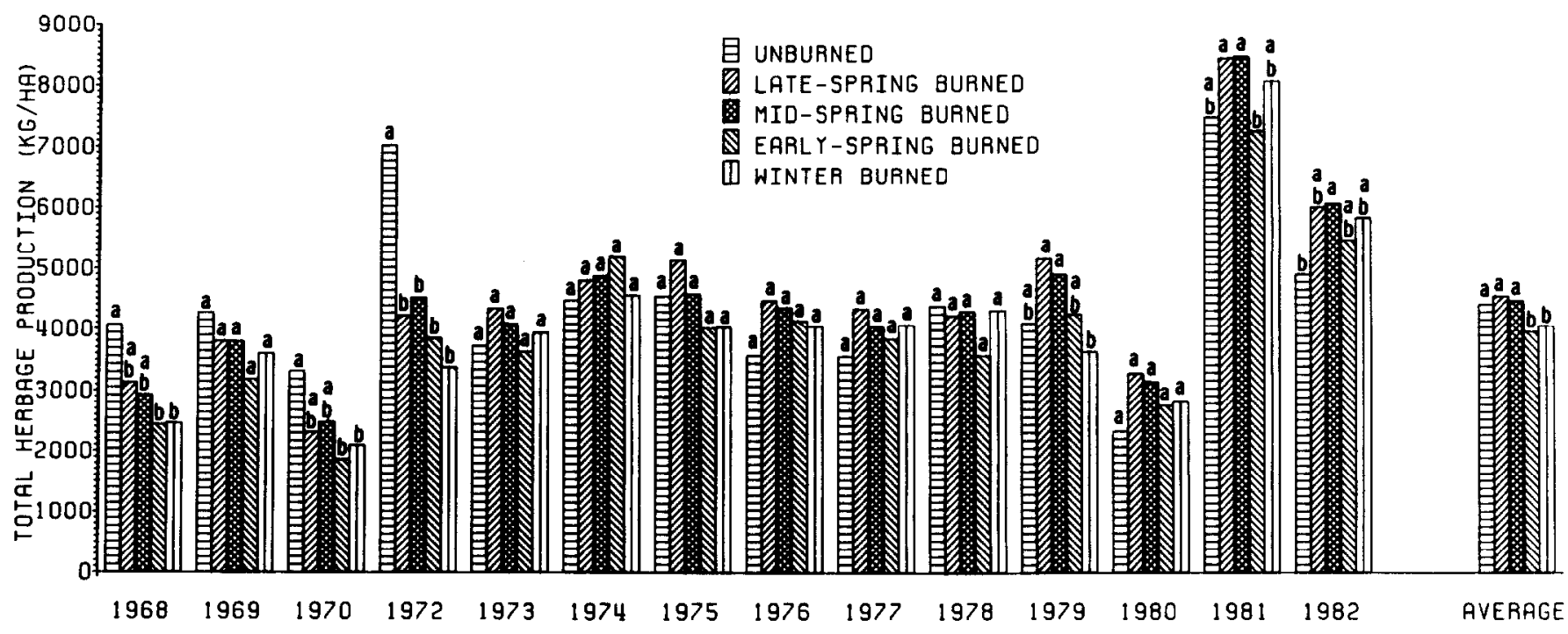

Fig. 3. Total annual herbage production ( $\mathrm{kg} / \mathrm{ha}$ oven-dry weight) from $1968-1982$ under different burning dates. Two replications per treatment. Mulch allowed to accumulate on unburned plots, but was excluded from yearly production data. Means within each year having the same letter are not significantly different $(\mathbf{P}>$.05). 
bage than burned plots for another 4 years (Fig. 3), but biomass from unburned plots undoubtedly was inflated in some years due to inadvertent harvesting of litter and old standing dead.

Total herbage production, however, may not be the most important criterion in assessing benefits from burning. Analysis of individual herbage components from 1973-1982 indicated that latespring burning significantly increased grass production and lowered forb production compared to any other treatment (Fig. 4).

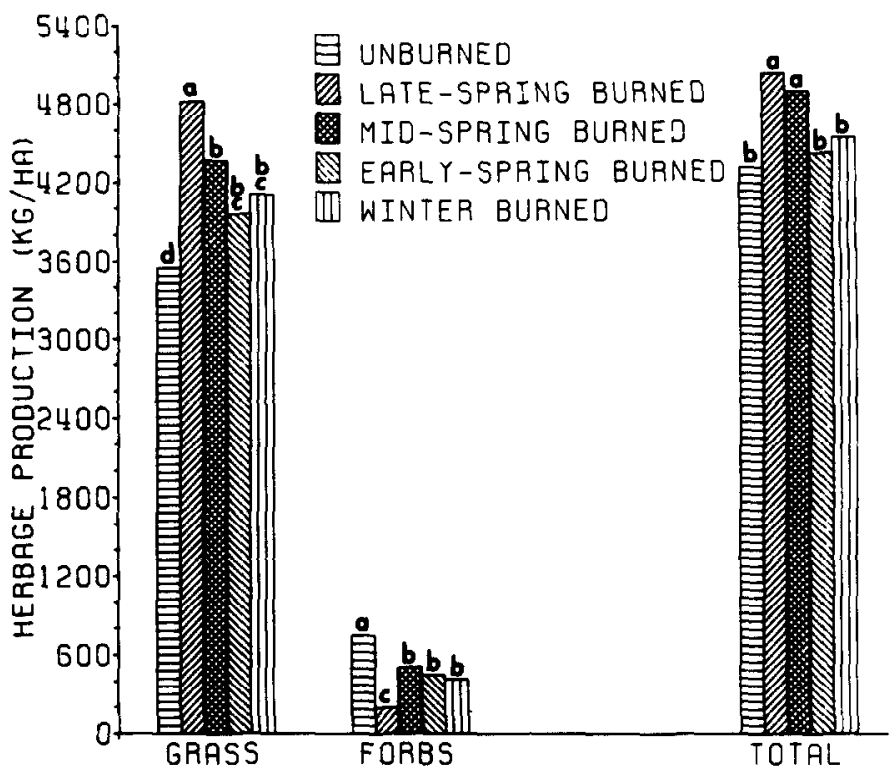

Fig. 4. Average grass, forb, and total production ( $\mathrm{kg} / \mathrm{ha}$ oven-dry weight) from 1973-1982 under different burning dates. Litter and old standing dead in unburned plots were excluded from production data. Means within each component having the same letter are not significantly different (P>.05).

Unburned plots had the lowest grass and highest forb yields of any treatment. Burning in late-spring reduced forb production because most species were actively growing and at a low point in their carbohydrate reserves (Anderson et al. 1970). Grass yields increased from late-spring burning because fire at that time coincided with emergence of the dominant warm-season perennial grasses (Owensby and Anderson 1967).

\section{Botanical Census}

Long-term annual burning at various dates differentially affected plant species and shifted botanical composition from that prior to initiation of the study. Phenological development of a species at the time of burning largely determines its response to fire. Plants actively growing when burning occurs are more susceptible to fire injury than dormant species or those just initiating growth (Anderson et al. 1970).

\section{Andropogon gerardii Vitman}

Late-spring burning significantly increased big bluestem amounts compared to other treatments (Fig. 5). Since 1961, big bluestem consistently accounted for over $50 \%$ of the total vegetation in late-spring burned plots, indicating that it responds favorably to fire, particularly when burning occurs at the onset of spring growth. Unburned plots prior to 1968 contained lower amounts of big bluestem than other treatments; however, once yearly mulch removal was halted, relative density of big bluestem began increasing. Nearly pure stands of big bluestem eventually develop in ungrazed, heavily mulched prairie (Weaver and Rowland 1952, Hulbert 1969). Apparently, big bluestem is not adversely affected by fire exclusion when mulch accumulations inhibit competition from other species.

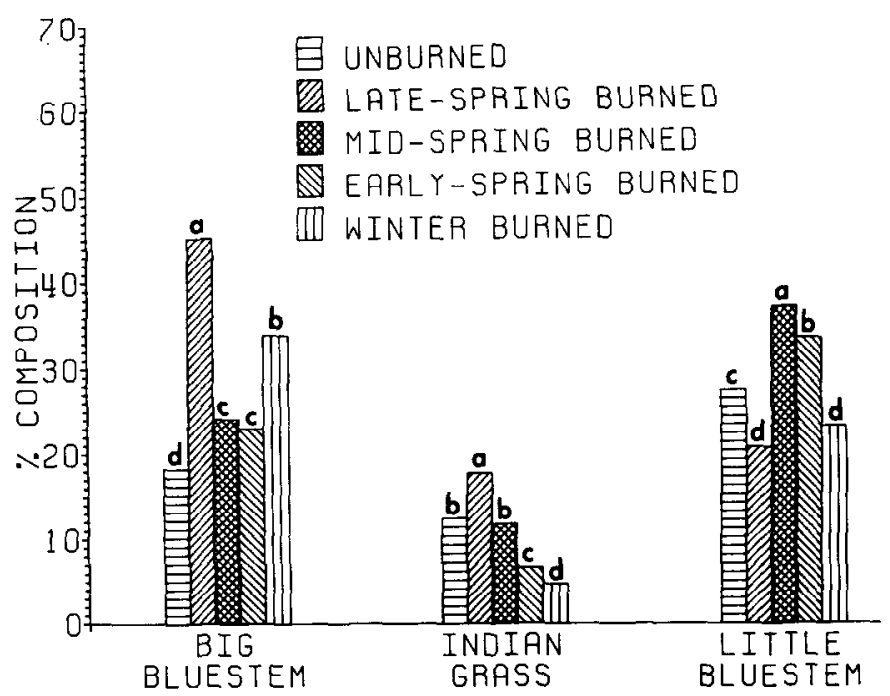

Fig. 5. Average \% composition of big bluestem, indiangrass, and little bluestem, indiangrass, and little bluestem from 1928-1982 under different burning dates. Means within each year having the same letter are not significantly different (P>.05).

\section{Sorghastrum nutans (L.) Nash}

Late-spring burning significantly increased indiangrass, while winter and early-spring burning reduced amounts compared to those of unburned plots (Fig. 5). Since 1976, big bluestem and indiangrass together have comprised over $90 \%$ of the total vegetation in late-spring burned plots. In unburned plots, indiangrass density began declining after 1973. Because indiangrass, unlike big bluestem, has indeterminant tillering (McKendrick et al. 1975), mulch accumulations likely inhibited tiller development.

\section{Andropogon scoparius Michx.}

Winter and late-spring burning adversely affected little bluestem, but mid-and early-spring burning significantly increased amounts compared to not burning (Fig. 5). Hensel (1923) and Aldous (1934)also noted that little bluestem was favored by earlyspring burning. In grazed pastures, however, Anderson et al. (1970) reported that little bluestem was reduced by early-spring, but not by late-spring burning. McMurphy and Anderson (1965) concluded that burning at any time was detrimental. Because little bluestem is a bunchgrass, the plant crown is susceptible to fire injury unless conditions are moist. Thus, discrepancies in the response of little bluestem to time of burning may reflect shortterm fluctuations in prevailing environmental conditions at ignition time.

Little bluestem often accounted for over $50 \%$ of the total vegetation, culminating at $75.8 \%$ in 1974 mid-spring burned plots. But the average percentage for all treatments fell from $43.6 \%$ in 1974 to $14.3 \%$ in 1975 . At that time, the randomized line transect method for determining vegetation composition was abandoned in favor of the modified step-point. Increased amounts of big bluestem, indiangrass, sedges, and perennial forbs offset little bluestem reduction in winter, early- and mid-spring burned plots. However, in unburned and late-spring burned plots, no species increases were associated with the changeover in sampling technique.

\section{Poa pratensis $\mathrm{L}$.}

Kentucky bluegrass, a cool-season perennial with low drought tolerance and inherently low productive capacity in Kansas, was effectively reduced by burning on all dates (Fig. 6). Fire essentially eliminated bluegrass because the plant was actively growing and susceptible to injury.

Fluctuation of Kentucky bluegrass in unburned plots was responsible for a significant interaction among years. That effect, however, was not correlated with precipitation $(r<.12$ for all inde- 


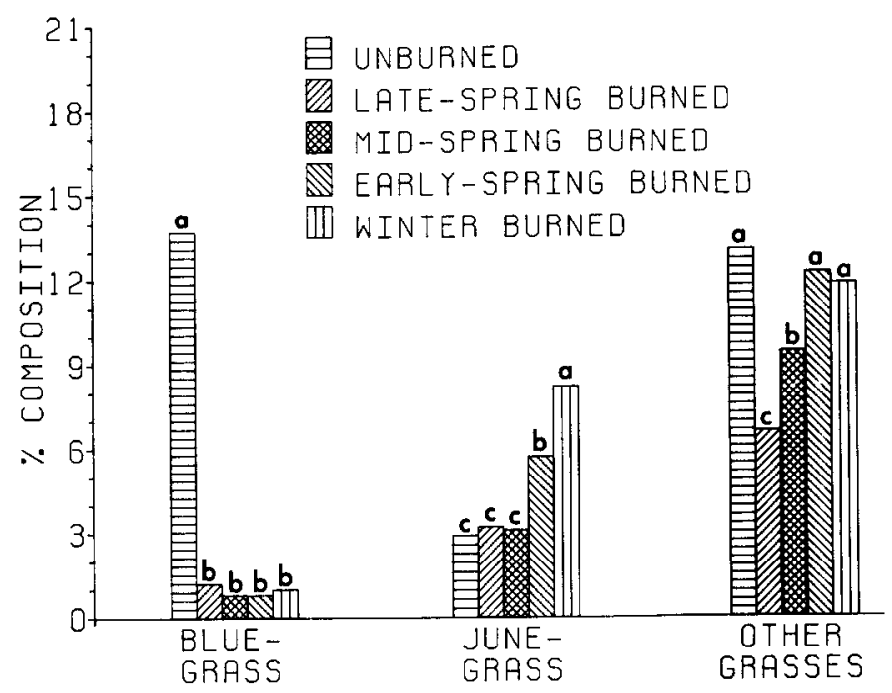

Fig. 6. Average \% composition of Kentucky bluegrass, prairie junegrass, and other perennial grasses from 1928-1982 under different burning dates. Means within each block having the same letter are not significantly different (P>.05).

pendent variables). Apparently, there was an interaction with mulch thickness because bluegrass began increasing in unburned plots 3 years after annual top growth removal ceased. Bluegrass peaked in 1979 at $34.8 \%$ of the total vegetation and then began progressively declining, probably because of dense mulch accumulations. Weaver and Rowland (1952) observed an absence of Kentucky bluegrass in heavily mulched tallgrass prairie undisturbed by fire, grazing, or mowing.

\section{Koeleria pyramidata (Lam.) Beauv.}

Prairie junegrass, another cool-season perennial, is not a dominant species in the tallgrass prairie, but was scgregated out because it accounted for $20-30 \%$ of the total vegetation in the 1920's. Unlike bluegrass, prairie junegrass was adversely affected by protection from fire but was favored by winter and early-spring burning (Fig. 6). That explains the high amount of junegrass present at the beginning of the study when it was common practice to burn in January or February.

\section{Other Perennial Grasses}

The remaining aggregate of perennial grass species decreased under late- and mid-spring burning (Fig. 6). Fire at that time favored big bluestem and indiangrass, which displaced other perennial grass species. Predominant recurring species in all plots included sideoats grama [ Bouteloua curtipendula (Michx.) Torr.], tall dropseed [Sporobolus asper (Michx.) Kunth var. asper], prairie dropseed [S. heterolepis (Gray) Gray] and Scribner's panicum [Panicum oligosanthes Schult. var. scribnerianum (Nash) Fern.]. Following the 1930's and 1950's drought, sideoats grama significantly increased, particularly in plots burned in winter, early-, and mid-spring. Otherwise, average composition of all the species remained relatively stable throughout the years, indicating their persistence as subdominants in the tallgrass prairie.

Switchgrass ( Panicum virgatum L.), considered a dominant in many parts of the tallgrass prairie, was not abundant enough for statistical evaluation and was analyzed with the other perennial grasses. Highest amounts of switchgrass were in unburned plots that were mowed and raked annually. However, after mulch removal was stopped, switchgrass stands declined. Under all burning treatments, switchgrass generally maintained a relative composition of less than $1 \%$.

\section{Sedges}

Early-spring and winter burning significantly increased the amount of sedges compared to not burning (Fig. 7). Late-spring burning essentially eliminated sedges, because growing season of the dominant genus, Carex, began in late March, making it susceptible to fire injury.

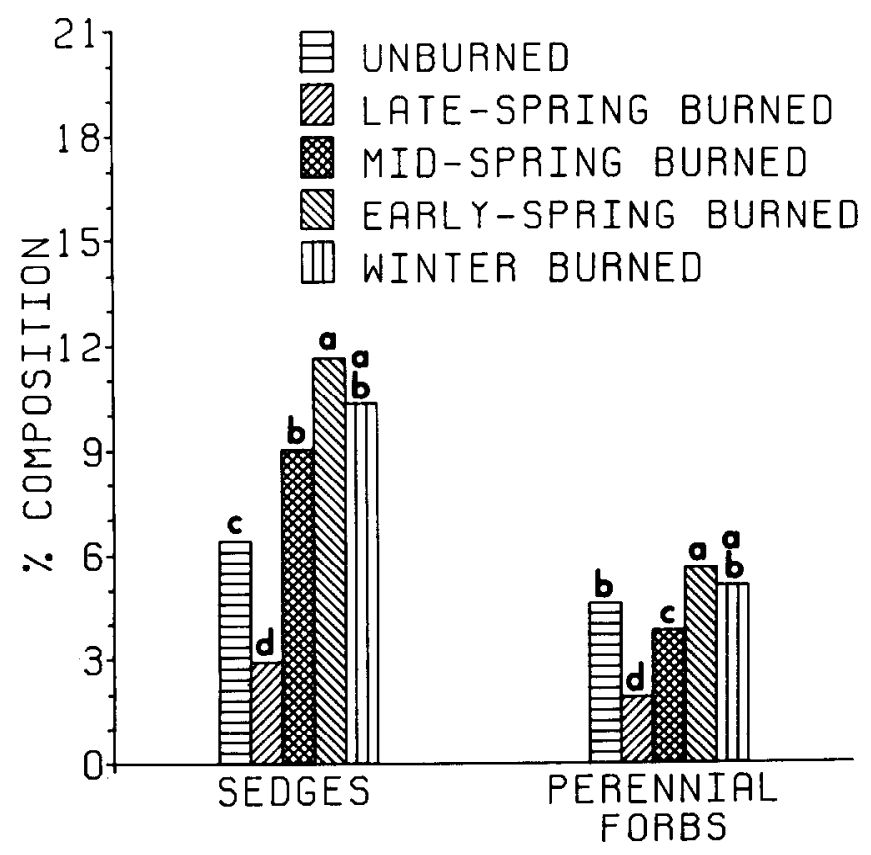

Fig. 7. Average \% composition of sedges and perennial forbs from 1928 1982 under different burning dates. Means within each block having the same letter are not significantly different $(\mathrm{P}>.05)$.

\section{Annual Grasses and Annual Forbs}

Annual grasses have been virtually nonexistent in any treatment since inception of the study. Although they never exceeded trace amounts, average percentage of annual grasses was highest in unburned plots and lowest in plots burned in late-spring. Sporadically appearing species included common witchgrass (Panicum capillare L.) and poverty dropseed [Sporobolus vaginiflorus (Torr.) Wood].

Annual forb populations also were insignificant, accounting for less than $1 \%$ of the vegetation in any treatment since 1950 . There was no significant difference among treatments $(P>.14)$. During the drought of the 1930's, however, a few species, primarily daisy fleabane (Erigeron strigosus Muhl.) and rough falsepennyroyal (Hedeoma hispida Pursh), flourished for a short period in all burned plots. Small amounts of snow-on-the-mountain (Euphorbia marginata Pursh) have occurred most years in unburned plots.

\section{Perennial Forbs}

Compared to other treatments, late-spring burning significantly reduced perennial forbs while burning in winter and early-spring favored them (Fig. 7). Throughout the years, perennial forb populations have remained relatively stable in each of the respective treatments. Predominant species that have survived repeated burnings include heath aster (Aster ericoides L.), showy goldenrod (Solidago speciosa Nutt.), and pitcher sage (Salvia pitcherii Torr.). In unburned plots, the dominant perennial forbs included Louisiana sagewort (Artemisia ludoviciana Nutt. var. ludoviciana) and western ragweed (Ambrosia psilostachya DC.).

\section{Woody Species}

Burning had a diverse effect on woody species, but composition in any treatment rarely exceeded $1 \%$ of the total vegetation. Plots burned in winter, early-, and mid-spring contained significantly higher amounts of woody plants than late-spring or unburned plots. That was because leadplant (Amorpha canescens Pursh), the 
only woody species occurring in burned plots, was favored by fire. Unburned plots, however, support thick stands of dogwood (Cornus drummondii Mey.), interspersed with Eastern redcedar (Juniperus virginiana $\mathrm{L}$.) and American elm (Elmus americana $\mathrm{L}$.). All trees in the unburned plots are saplings because annual mowing prior to 1968 prevented them from becoming established. In the absence of fire, tree species progressively invade and will eventually dominate tallgrass prairie (Bragg and Hulbert 1976).

Buckbrush (Symphoricarpos orbiculatus Moench), a shrub species normally infesting unburned prairie, has not yet invaded the experimental area. Previous mowing of unburned plots in latespring coincided with the low point in buckbrush carbohydrate reserve cycle and would effectively control it (Aldous 1934).

\section{Total Basal Cover}

Total basal cover was highest in plots burned in mid- and earlyspring (Fig. 8). Burning at that time favors little bluestem, a bunchgrass, which would account for the increased basal coverage.

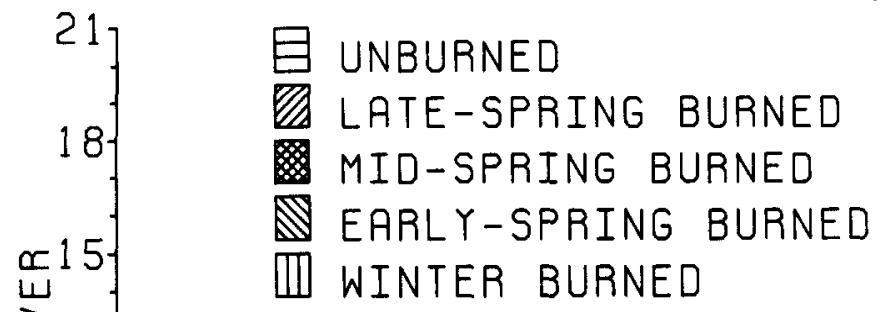

\section{TREATMENT}

Fig. 8. Average \% of total basal cover from 1950-1982 under different burning dates. Means having the same letter are not significantly different $(\mathrm{P}>$.05).

Unburned plots had significantly lower basal cover than any other treatment, particularly after mowing stopped, indicating that accumulated mulch reduced plant basal cover. Total basal cover was lowest in 1956 following a prolonged drought, but there were no significant differences among burning treatments. There was also no year by treatment interaction, indicating that despite opinions to the contrary, burning tallgrass prairie in dry years does not adversely affect total basal cover compared to not burning.

\section{Conclusions}

Time of burning has a profound effect on the vegetational response to fire. The closer time of burning is to initiation of spring growth, the more favorable the response. Our data indicate that only 3 weeks difference in time of spring burning has a dramatic long-term influence on the vegetation. Yet most studies have not addressed the importance of when a burn occurred. Reported discrepancies in the effects of fire on herbage yield and species composition in tallgrass vegetation likely are due to differences in time of burning.

Differential response of plant species to time of burning allows for manipulation of vegetation. In Kansas tallgrass prairie, annual burning in late-spring will maximize yield and composition of big bluestem and indiangrass. Burning earlier in spring will reduce herbage yields, but will increase species diversity and benefit perennial forbs. Unburned, prairie deteriorates in both grass production and species composition.

\section{Literature Cited}

Adams, D.E., and R.C. Anderson. 1978. The response of a central Oklahoma grassland to burning. Southwestern Natur. 23:623-632.

Aldous, A.E. 1934. Effect of burning on Kansas bluestem pastures. Kansas Agr. Exp. Sta. Bull. 38.

Anderson, K.L. 1942. A comparison of line transects and permanent quadrats in evaluating composition and density of pasture vegetation of the tall prairie grass type. J. Amer. Soc. Agron. 34:805-822.

Anderson, K.L. 1965. Time of burning as it affects soil moisture in an ordinary upland bluestem prairie in the flint hills. J. Range Manage. 18:311-316.

Anderson, K.L., E.F. Smith, and C.E. Owensby. 1970. Burning bluestem range. J. Range Manage. 23:81-92.

Bieber, G.L., and K.L. Anderson. 1961. Soil moisture in bluestem grassland following burning. J. Soil and Water Conserv. 16:186-187.

Bragg, T.B., and L.C. Hulbert. 1976. Woody plant invasion of unburned Kansas bluestem prairie. J. Range Manage. 29:19-24.

Hensel, R.L. 1923. Effect of burning on vegetation in Kansas pastures. J. Agr. Research. 23:631-643.

Hulbert, L.C. 1969. Fire and litter effects in undisturbed bluestem prairie in Kansas. Ecology 50:874-877.

Jackson, A.S. 1965. Wildfires in the great plains grasslands. Tall Timbers Fire Ecol. Conf. Proc. 4:241-259.

Kollmorgen, W.M., and D.S. Simonett. 1965. Grazing operations in the flint hills-bluestem pastures of Chase County, Kansas. Ann. Ass. Amer. Geo. 55:260-290.

McGregor, R.L., and T.M. Barkley. 1977. Atlas of the flora of the great plains. lowa State Univ. Press, Ames.

McKendrick, J.D., C.E. Owensby, and R.M. Hyde. 1975. Big bluestem and indiangrass vegetative reproduction and annual reserve carbohydrate and nitrogen cycles. Agro-Ecosystems. 2:75-93.

McMurphy, W.E., and K.L. Anderson. 1963. Burning bluestem rangeforage yields. Trans. Kansas Acad. Sci. 66:49-51.

McMurphy, W.E., and K.L. Anderson. 1965. Burning flint hills range. J. Range Manage. 18:265-269.

Owensby, C.E. 1973. Modified step-point system for botanical composition and basal cover estimates. J. Range Manage. 26:302-303.

Owensby, C.E., and K.L. Anderson. 1967. Yield responses to time of burning in the Kansas flint hills. J. Range Manage. 20:12-16.

Penfound, W.T. 1964. Effects of denudation on the productivity of grassland. Ecology. 45:838-845.

Rice, E.L., and R.L. Parenti. 1978. Causes of decreases in productivity in undisturbed tall grass prairie. Amer. J. Bot. 65:1091-1097.

Stewart, 0.C. 1951. Burning and natural vegetation in the United States. Geo. Rev. 41:317-320.

Weaver, J.E., and N.W. Rowland. 1952. Effects of excessive natural mulch on development, yield, and structure of native grassland. Bot. Gaz. 114:1-19. 